\title{
Incidence of Appendicular Bone Fracture in Dogs and Cats: Retrospective Study at Veterinary Hospital of Cairo University and some Private Clinics in Egypt
}

\author{
Abeer Ali Mahmoud Abo-Soliman, Ahmed Elsayed Ahmed and Haithem Ali Mohamed Ahmed Farghali* \\ Department of Surgery, Anesthesiology, and Radiology, Faculty of Veterinary Medicine, Cairo University, Egypt \\ * Corresponding author's Email address: dr_haithem0@yahoo.com; (DORCiD: 0000-0002-3311-1335
}

\begin{abstract}
Appendicular bone fractures in small animal practice constitute a major challenge facing veterinary orthopedic surgeons concerning affected limb and bone as well as the extent of tissue damage, site, and shape of the fracture line. Therefore, this retrospective study was designed to provide descriptive data at referral veterinary teaching hospital, faculty of veterinary medicine, Cairo University, and some private pet clinics in Cairo district, Egypt to identify and determine the prevalence of appendicular fractures arising from trauma in dogs and cats treated from January 2017 to January 2020, and emphasizing the information that characterized the population (breed, age, gender, and animal size). The investigated fractures were classified according to the specific limb (forelimbs / hind limbs), specific bone fractures (Humerus, radius and ulna, femur, tibia and fibula, and the other bones), extent of tissue damage (open or closed and incomplete or complete), site (proximal, diaphyseal or distal zones), number (single or comminuted), and the direction of the fracture line (transverse, oblique or spiral). From the obtained data, it could be concluded that there was a high incidence of the appendicular long bones concerning the different bone fractures with significantly higher records in dogs, compared to cats. The highest records of fracture were in mongrel dogs, and cats as rescued animals. Excluding mongrel dogs and cats, the highest incidence of fracture-cases in dogs was recorded in Miniature breeds and svelte breeds for cats. Male dogs and cats showed a higher incidence than females. The bone fracture mostly occurred in dogs younger than one-year-old, and cats aged one to three years. A fracture in the hindlimbs was more significant than forelimbs with the highest incidence in femoral bone among both dogs and cats. The percentage of open fractures were more common in cats than dogs. Incomplete fractures were recorded more frequently in dogs than cats. In dogs, the most common fractures in the femur, tibia/fibula, humerus, and radius/ulna were complete comminuted diaphyseal femoral, complete oblique diaphyseal tibial/fibular, complete transverse distal humoral, and complete transverse diaphyseal radial/ulnar fractures respectively. Moreover, cats were complete transverse distal femoral, complete oblique diaphyseal tibial/fibular, complete spiral diaphyseal humoral, and complete transverse distal radial/ulnar fractures. In conclusion, appendicular bone fracture among dogs and cats referred to the veterinary teaching hospital, Cairo University and some private clinics in Egypt showed high incidence $(87 \%$ in dogs and $71.8 \%$ in cats) out of total fracture cases and this incidence correlated with some predisposing factors (including breeds, weight, age, and gender) and causative agents that resulted in different types of appendicular fractures.
\end{abstract}

Keywords: Cat, Dog, Femur, Fracture, Orthopedic

\section{INTRODUCTION}

Orthopedic cases constitute a major percentage of surgery caseload in most of veterinary clinics and referral centers in different parts of the world (Appari et al., 2013). Bone fractures, especially in long bones, constitute a major problem in small animal practice particularly in dogs (Gadallah et al., 2009). Violent trauma with a vehicular accident or minimal trauma with a pathological condition such as neoplasia usually are the most common causes of fractures (Beale, 2004; Fossum, 2013). The diagnosis of fractures is based on a history of trauma and clinical signs. Radiography, ultrasonography, and histology have been used as the tools for fracture-healing assessment (Rrisselada et al., 2005). When regular serial radiographs are available, they aid in monitoring the progress of bone healing, and facilitate the decision-making procedure for the removal of orthopedic implants (Hobbs, 2012).

It is extremely important to carry out retrospective and prospective studies to determine the prevalence of the most common diseases in a given geographic region (Chaves et al., 2014). The incidence of bone fractures in dogs and cats have been reported in different regions of the world (Thengchaisri et al., 2006; Shiju et al., 2010; Minar et al., 2013; Rhangani, 2014; Elzomor et al., 2014; Libardoni et al., 2016 and Lovrić et al., 2020).

A standardized description of a fracture is an important issue as it directs the orthopedic surgeons to classifying it very cautiously, thereby to choose the proper method of reduction, fixation and immobilization. Classification of appendicular fractures was extensively discussed (Harari, 2002; Lanz, 2002; Piermattei et al., 2006; Shales, 2008a and 2008b). Fractures could be classified according to different aspects of cause; open or closed, extent of bone damage, 
number and position of fracture lines, direction, location, forces acting on the fracture, stability, degree of soft tissue damage and age of the fracture. According to the cause of the fracture, fractures are classified into intrinsic (muscular, pathological and stress) and extrinsic (external trauma). Regarding the extent of bone damage, fractures are classified into incomplete (greenstick, fissure and depressed) and complete. According to the number and position of the fracture lines, they are classified into simple, segmental and comminuted. According to the direction of fracture lines, they are classified into transverse, oblique and spiral. According to direction of fracture location, fractures are classified into diaphyseal (proximal, mid or distal), metaphyseal, articular, condylar and physeal (classified according to the salterharris system). Regarding the forces acting on the fracture site, fractures are classified into avulsion, impaction, compression and displacement. According to the stability, they are classified into stable (interlocking fragments may have inherent stability and be suitable for external coaptation or conservative management) and unstable (fractures are usually unstable, and they require stabilization in order to facilitate the weight-bearing and healing). Regarding the degree of age of fracture, fractures are classified into recent (having sharp fracture edges) and old (rounded edges form after 10 to 14 days or there is the callus formation) (Shales, 2008a).

Knowing the types and frequency of fractures in domestic animals, the professionals in the area of orthopedics and veterinary physiotherapy can direct their attention to the improvement of fixation techniques, correction and stabilization of fractures, thus increasing the efficiency in the treatment and repair (Vidane et al., 2014). Fossum (2013) suggested a fracture-assessment scoring system which includes three different factors; mechanical, biological, and clinical. Mechanical factors include a reducibility of the fracture, patient size and weight, and if an injury or a disease is present on other limbs. Evaluation of mechanical factors helps to evaluate how strong the fracture fixation should be for the individual patient. Biological factors take into account the age and general health of the patient, extent of the soft tissue damage around the fracture both due to high-velocity injury and the surgeon's skills during fracture repair. The biological factors play a role in estimating the healing time of the fracture. Clinical factors help to assess the fracture healing during the postoperative period. It includes the patients' and owner's compliance, the activity level of the patient, and the comfort during the fracture healing. The three factors should all be taken into account when the prognosis of a fracture and fracture surgery are assessed. Fractures with high scores generally heal with lower complication risks, whereas fractures assigned lower scores one can expect a greater risk for complications.

This retrospective study aimed to provide descriptive data at referral veterinary teaching hospital, faculty of veterinary medicine, Cairo University, and some private pet clinics in Cairo district, Egypt to identify and determine the prevalence of dogs and cats with appendicular fractures arising from a trauma treated from January 2017 to January 2020, and emphasizing the information that characterized the population (breed, age, gender, and size).

\section{MATERIALS AND METHODS}

\section{Ethical approval}

All procedures (including data collections, patients' information recording at the referral veterinary teaching hospital, Cairo University and some private clinics in Egypt and radiographs interpretations) of the current study were approved by the Institutional Animal Care and Use Committee, Cairo University (Vet CU 20022020127).

\section{Data collection}

Data were collected from patient's medical records at referral veterinary teaching hospital, faculty of veterinary medicine, Cairo University, and some private pet clinics in Cairo district, Egypt. Searches were made on all fractures during the period from January 2017 to January 2020. Dogs and cats with fractures were confirmed by the history, clinical, orthopedic, and radiographic examinations, then were submitted to osteosynthesis surgical treatment which was not included in this study.

\section{Patients' information}

Basic information about the patients included breeds, weight, age, sex, and causative agent were recorded. All dog breeds were listed according to Federation Cynologique Nationale (FCI), the World Canine Organization. Breeds not recognized by FCI were categorized as mixed-breed. Regarding dogs, 34 breeds were admitted to the hospital and clinics, while fracture was recorded in $18 \mathrm{dog}$ breeds (English Bullmastiff, Saint Bernard, German Shepherd, Golden Retriever, German Rottweiler, Labrador Retriever, Siberian Husky, Alaskan Husky, American Pitbull, Mongrel (Mixedbreed), Doberman Pinscher, Grand Griffon Vendèen, Petit Basset Griffon Vendèen, English Cocker Spaniel, American Cocker Spaniel, Yorkshire Terrier, Pomeranian, and Chihuahua). Regarding cats, six breeds were admitted to the hospital and clinics, while the fracture was recorded in five cat breeds (Persian, Mongrel (Mixed-breed), Himalayan, Siamese, and Egyptian Mau).

The dog breeds were categorized according to body size or weight into Giant (more than $45 \mathrm{~kg}$ ), Large (22-45 kg), Medium (12-22 kg), Small (5-12 kg), and Mini or toy breeds (less than $5 \mathrm{~kg}$ ) (American Kennel Club, 2006; Fogle, 2009). 
Cat breeds were categorized according to body conformation types to three general groups: cobby, such as the Persian and Himalayan cat breeds; svelte, such as the Siamese, Egyptian Mau, and Sphynx cat breeds, and moderate such as the mongrel cat breed. The cobby's body design is short and compact, deep-chested, and broad across the shoulders and rump. The head is also large and round, and the tail is often shorter and blunt at the tip. In contrast, the svelte type is very slim and lithe with long tapering lines. The head is narrow and forms a wedge shape, and the tail is usually long, slender, and pointed at the tip. The moderate lies are between these two types, and is neither cobby nor svelte; several breeds are moderate in conformation (Helgren, 2013). Dogs' and cats' gender were recorded to study the relations between the incidence of fracture and gender of affected cases._Regarding the age, the animals were distributed into four age groups: Juvenile, puppies or kitten (less than 1 year), young adult (1-3 years), mature adult (3-10 years), and elder (over 10 years old) according to the methodology used in a case study (Shearer, 2011). Data about different causes of fracture were collected from the owners to evaluate the relations between the incidence of fracture and their causes.

\section{Establishment of the types and frequency of bone fractures' occurrence}

Fractures were classified according to Shales (2008b):

Classification of bone fracture based on the body parts, the incidence of specific limb and specific bone fractures which includes

a- Incidence of specific limb (forelimbs / hind limbs) fractures

b- Incidence of specific appendicular bone fractures. Forelimb (Humerus, radius and ulna), Hindlimb (Femur, tibia and fibula.), and the number of the other bone fractures were recorded.

Frequency of the different types of appendicular bone fracture based on the extent of tissue damage, site, and shape of the fracture line

a- The extent of tissue damage: 1) Open or closed fracture; 2) Incomplete or complete fracture.

b- Fracture location: Proximal, diaphyseal or distal zones

c- Fracture line: 1) The number of fracture line (single or comminuted); 2) The direction of fracture line (transverse, oblique or spiral)

\section{Statistical analysis}

Data that were collected about age, sex, and breeds were collected, and they were added to the Microsoft Excel 2010R spreadsheet, stored separately and exported to analytical software using the Chi-square test. Values of $<0.05$ were considered as statistically significant.

\section{RESULTS}

\section{Patients' information}

\section{Breeds, weight, age, gender, and causative agent}

Out of 4625 cases of dogs (table 1) and 3712 cats (table 2) admitted to the hospital and clinics, a total of 324 (7.01\%) records of dogs and $149(4.01 \%)$ of cats were diagnosed with fractures which were selected from X-ray records at referral veterinary teaching hospital, faculty of veterinary medicine, Cairo University and some private pet clinics in Cairo district, Egypt; covering the period from January 2017 to January 2020.

Regarding dog breeds, the fracture was recorded in 18 breeds. The distribution of appendicular fractures among the different breeds of dogs in the present study is presented in table 3. The most affected breeds were Mongrel (Mixedbreed, 61.74\%), Pomeranian (22.22\%), Chihuahua (13.33\%), Yorkshire Terrier (7.41\%), Siberian Husky (5.56\%), Golden Retriever (5.36\%), German Shepherd (5.19\%), American Cocker Spaniel (4.08\%), German Rottweiler (3.90\%), Alaskan Husky (3.26\%) and Grand Griffon Vendèen (3.26\%). Regarding cat breeds, the fracture was recorded in five breeds. The distribution of appendicular fractures among the different breeds of cats in the currents study is presented in table 4. The most affected breeds were Mongrel (Mixed-breed, 14.01\%), Siamese (3.17\%), Persian (1.99\%), Himalayan $(1.85 \%)$, and Egyptian Mau (1.47\%). According to the body size or weight, the dog breeds were categorized into five groups; Giant, Large, Medium, Small, and Mini breeds (Table 5). The most affected breed according to the size was medium $(26.84 \%)$, followed by mini (13.33\%), large (4.83\%), small (2.73\%), and giant (1.89\%) breeds. According to the body conformation, the cat breeds were categorized into three groups; Cobby, Moderate, and Svelte breeds (Table 6). The most affected breed according to the body conformation was moderate $(14.01 \%)$, followed by svelte $(2.58 \%)$ and cobby $(1.98 \%$ ) breeds. Regarding the gender (table 7), the incidence of fractures in male dogs was $65.43 \%$ out of total fracture cases; $7.61 \%$ out of total admitted male dogs and $4.58 \%$ out of total admitted (male and female) dogs, and the incidence of fractures in female dogs was $34.57 \%$ out of total fracture cases; $6.08 \%$ out of total admitted female dogs and $2.42 \%$ out of total admitted (male and female) dogs. Meanwhile, in cats, the incidence of fractures in male cats was 
$66.44 \%$ out of total fracture cases; $6.81 \%$ out of total admitted male cats and $2.67 \%$ out of total admitted (male and female) cats, while the incidence of fractures in female cats was $33.56 \%$ out of total fracture cases; $2.21 \%$ out of total admitted female cats and $1.35 \%$ out of total admitted (male and female) cats.

Regarding the age (table 8), the incidence of the fracture in dogs were $54.94 \%, 29.63 \%, 12.96 \%$, and $2.47 \%$ out of dog fracture cases; $10.72 \%, 6.93 \%, 3.09 \%$, and $3.64 \%$ out of total admitted dogs of related age and $3.85 \%, 2.08 \%$, $0.91 \%$, and $0.17 \%$ out of total admitted dogs, distributing among ages (Juvenile ( $<1$ year), young adult (1-3 years), mature adult (3-10 years) and Elder (> 10 years)), respectively. Meanwhile, in cats, the incidence of bone fracture was $32.89 \%, 34.23 \%, 24.83 \%$, and $8.05 \%$ out of cat fracture cases; $3.94 \%, 5.99 \%, 3.84 \%$, and $1.83 \%$ out of total admitted cats of related age and $1.32 \%, 1.37 \%, 1.00 \%$, and $0.32 \%$ out of total admitted cats, distributing among ages (Juvenile (< 1 year), young adult (1-3 years), mature adult (3-10 years) and Elder (> 10 years)), respectively.

The obtained results (table 9) showed that the causes of presented fracture cases in dogs and cats were trauma due to traffic accidents (141 dogs, $43.5 \%$ and 74 cats, 49.7\%), falling from a height (63 dogs, 19.4\% and 54 cats, $36.2 \%)$, indoor trauma (18 dogs, $5.6 \%$ and 8 cats, $5.4 \%$ ), pathological conditions ( $12 \mathrm{dogs}, 3.7 \%$ and 2 cats, $1.3 \%$ ), animal bite (10 dogs, 3.1\%) and human abuse (9 dogs, 2.8\%), respectively. The cause which cannot be defined in 82 cases of fractures $(71 \mathrm{dogs}, 25.6 \%$, and 11 cats, $8.7 \%$ ) was because the owners had not witnessed the moment of the event.

Table 1. The total admitted dog cases to the Referral Veterinary Teaching Hospital, Cairo University and some Private Clinics in Egypt from January 2017 to January 2020.

\begin{tabular}{|c|c|c|c|c|c|c|}
\hline \multirow{3}{*}{ Dog breeds } & \multirow{3}{*}{$\begin{array}{l}\text { Routine works } \\
\text { (Vaccinations, } \\
\text { deworming, } \\
\text { external } \\
\text { parasite control, } \\
\text { etc.) }\end{array}$} & \multirow{3}{*}{$\begin{array}{l}\text { Medicinal } \\
\text { cases }\end{array}$} & \multicolumn{3}{|c|}{ Surgical cases } & \multirow{3}{*}{ Total } \\
\hline & & & \multirow{2}{*}{$\begin{array}{c}\text { Soft tissue } \\
\text { surgical } \\
\text { cases }\end{array}$} & \multicolumn{2}{|c|}{ Orthopedic surgical cases } & \\
\hline & & & & $\begin{array}{l}\text { Fracture } \\
\text { cases }\end{array}$ & $\begin{array}{c}\text { Joint affected } \\
\text { cases }\end{array}$ & \\
\hline 1. German Shepherd & 428 & 282 & 126 & 62 & 296 & 1194 \\
\hline 2. Golden Retriever & 206 & 141 & 116 & 36 & 173 & 672 \\
\hline 3. German Rottweiler & 123 & 104 & 80 & 18 & 136 & 461 \\
\hline 4. American Pit bull & 112 & 87 & 82 & 4 & 28 & 313 \\
\hline 5. Mongrel (Mixed-breed) & 16 & 13 & 66 & 163 & 6 & 264 \\
\hline 6. Grand Griffon Vendèen & 68 & 55 & 72 & 7 & 13 & 215 \\
\hline 7. Labrador Retriever & 52 & 46 & 18 & 5 & 48 & 169 \\
\hline $\begin{array}{l}\text { 8. Petit Basset Griffon } \\
\text { Vendèen }\end{array}$ & 62 & 48 & 27 & 2 & 8 & 147 \\
\hline 9. French Bullmastiff & 42 & 48 & 13 & 0 & 44 & 147 \\
\hline 10. Siberian Husky & 49 & 42 & 12 & 7 & 16 & 126 \\
\hline 11. Maltese & 55 & 18 & 29 & 0 & 7 & 109 \\
\hline 12. English Cocker Spaniel & 47 & 37 & 11 & 3 & 3 & 101 \\
\hline 13. Alaskan Husky & 42 & 28 & 7 & 3 & 12 & 92 \\
\hline 14. English Bullmastiff & 36 & 22 & 11 & 1 & 19 & 89 \\
\hline 15. Saint Bernard & 20 & 18 & 11 & 2 & 19 & 70 \\
\hline 16. Neapolitan Mastiff & 22 & 16 & 13 & 0 & 9 & 60 \\
\hline 17. French Bulldog & 27 & 19 & 2 & 0 & 3 & 51 \\
\hline 18. American Cocker Spaniel & 34 & 7 & 4 & 2 & 2 & 49 \\
\hline 19. Doberman Pinscher & 28 & 12 & 6 & 1 & 2 & 49 \\
\hline 20. Cane Corso & 31 & 9 & 2 & 0 & 1 & 43 \\
\hline 21. Caucasian Shepherd & 13 & 7 & 0 & 0 & 11 & 31 \\
\hline 22. Yorkshire Terrier & 16 & 2 & 3 & 2 & 4 & 27 \\
\hline 23. German Boxer & 11 & 7 & 6 & 0 & 0 & 24 \\
\hline 24. Great Dane & 10 & 6 & 0 & 0 & 7 & 23 \\
\hline 25. Pekingese & 12 & 2 & 6 & 0 & 1 & 21 \\
\hline 26. Pomeranian & 7 & 5 & 0 & 4 & 2 & 18 \\
\hline 27. Chihuahua & 8 & 2 & 0 & 2 & 3 & 15 \\
\hline $\begin{array}{l}\text { 28. Alabai (Central Asian } \\
\text { Shepherd) }\end{array}$ & 6 & 2 & 0 & 0 & 5 & 13 \\
\hline 29. Chinese Pug & 4 & 1 & 1 & 0 & 2 & 8 \\
\hline 30. Rhodesian Ridgeback & 6 & 0 & 0 & 0 & 1 & 7 \\
\hline 31. Chow-Chow & 5 & 0 & 0 & 0 & 2 & 7 \\
\hline 32. Belgian Malinois & 5 & 0 & 0 & 0 & 0 & 5 \\
\hline 33. Basset Hound & 1 & 0 & 0 & 0 & 2 & 3 \\
\hline 34. Dalmatian & 2 & 0 & 0 & 0 & 0 & 2 \\
\hline Total & 1606 & 1086 & 724 & 324 & 885 & 4625 \\
\hline$\%$ & $34.72 \%$ & $23.48 \%$ & $15.65 \%$ & $7.01 \%$ & $19.14 \%$ & $100 \%$ \\
\hline
\end{tabular}


Table 2. The total admitted cat cases to the Referral Veterinary Teaching Hospital, Cairo University and some Private Clinics in Egypt from January 2017 to January 2020.

\begin{tabular}{|c|c|c|c|c|c|c|}
\hline \multirow{3}{*}{ Cat breeds } & \multirow{3}{*}{$\begin{array}{l}\text { Routine works } \\
\text { (Vaccinations, } \\
\text { deworming, } \\
\text { external parasite } \\
\text { control, etc.) }\end{array}$} & \multirow{3}{*}{$\begin{array}{l}\text { Medicinal } \\
\text { cases }\end{array}$} & \multicolumn{3}{|c|}{ Surgical cases } & \multirow{3}{*}{ Total } \\
\hline & & & \multirow{2}{*}{$\begin{array}{c}\text { Soft tissue } \\
\text { surgical } \\
\text { cases }\end{array}$} & \multicolumn{2}{|c|}{ Orthopedic surgical cases } & \\
\hline & & & & $\begin{array}{c}\text { Fracture } \\
\text { cases }\end{array}$ & $\begin{array}{c}\text { Joint affected } \\
\text { cases }\end{array}$ & \\
\hline 35. Persian & 638 & 1543 & 478 & 54 & 2 & 2715 \\
\hline 36. Mongrel (Mixed-breed) & 112 & 107 & 315 & 87 & 0 & 621 \\
\hline 37. Himalayan & 38 & 104 & 16 & 3 & 1 & 162 \\
\hline 38. Siamese & 26 & 87 & 7 & 4 & 2 & 126 \\
\hline 39. Egyptian Mau & 7 & 38 & 22 & 1 & 0 & 68 \\
\hline 40. Sphynx & 11 & 6 & 3 & 0 & 0 & 20 \\
\hline Total & 832 & 1885 & 841 & 149 & 5 & 3712 \\
\hline$\%$ & $22.41 \%$ & $50.78 \%$ & $22.66 \%$ & $4.01 \%$ & $0.14 \%$ & $100 \%$ \\
\hline
\end{tabular}

Table 3. Number and percentage of fracture cases out of total cases admitted to the Referral Veterinary Teaching Hospital, Cairo University and some Private Clinics in Egypt from January 2017 to January 2020 in relation to different dog breeds.

\begin{tabular}{|c|c|c|c|}
\hline Dog breeds & Total admitted cases & Fracture cases & $\begin{array}{l}\text { Percentage out of the total number } \\
\text { of admitted breed cases }\end{array}$ \\
\hline 1. Mongrel (Mixed-breed) & 264 & 163 & $61.74 \%$ \\
\hline 2. Pomeranian & 18 & 4 & $22.22 \%$ \\
\hline 3. Chihuahua & 15 & 2 & $13.33 \%$ \\
\hline 4. Yorkshire Terrier & 27 & 2 & $7.41 \%$ \\
\hline 5. Siberian Husky & 126 & 7 & $5.56 \%$ \\
\hline 6. Golden Retriever & 672 & 36 & $5.36 \%$ \\
\hline 7. German Shepherd & 1194 & 62 & $5.19 \%$ \\
\hline 8. American Cocker Spaniel & 49 & 2 & $4.08 \%$ \\
\hline 9. German Rottweiler & 461 & 18 & $3.90 \%$ \\
\hline 10. Alaskan Husky & 92 & 3 & $3.26 \%$ \\
\hline 11. Grand Griffon Vendèen & 215 & 7 & $3.26 \%$ \\
\hline 12. English Cocker Spaniel & 101 & 3 & $2.97 \%$ \\
\hline 13. Labrador Retriever & 169 & 5 & $2.96 \%$ \\
\hline 14. Saint Bernard & 70 & 2 & $2.86 \%$ \\
\hline 15. Doberman Pinscher & 49 & 1 & $2.04 \%$ \\
\hline 16. Petit Basset Griffon Vendèen & 147 & 2 & $1.36 \%$ \\
\hline 17. American Pitbull & 313 & 4 & $1.28 \%$ \\
\hline 18. English Bullmastiff & 89 & 1 & $1.12 \%$ \\
\hline Total & 4071 & 324 & $7.96 \%$ \\
\hline
\end{tabular}

Table 4. Number and percentage of fracture cases out of total cases admitted to the Referral Veterinary Teaching Hospital, Cairo University and some Private Clinics in Egypt from January 2017 to January 2020 in relation to different cat breeds.

\begin{tabular}{lccc}
\hline Cat breeds & Total admitted cases & Fracture cases & $\begin{array}{c}\text { Percentage out of the total number } \\
\text { of admitted breed cases }\end{array}$ \\
\hline 19. Persian & 2715 & 54 & $1.99 \%$ \\
20. Mongrel (Mixed-breed) & 621 & 87 & $14.01 \%$ \\
21. Himalayan & 162 & 3 & $1.85 \%$ \\
22. Siamese & 126 & 4 & $3.17 \%$ \\
23. Egyptian Mau & 68 & 1 & $1.47 \%$ \\
Total & 3692 & 149 & $4.04 \%$ \\
\hline
\end{tabular}


Table 5. Incidence of the fracture among affected dog breeds (Classified according to the body weight).

\begin{tabular}{|c|c|c|c|}
\hline & Dog breeds & Fracture cases & The percentage from admitted breed \\
\hline \multirow{3}{*}{$\begin{array}{l}\text { Giant breeds } \\
\text { Over } 45 \mathrm{~kg}\end{array}$} & English Bullmastiff & 1 & $1.12 \%$ \\
\hline & Saint Bernard & 2 & $2.86 \%$ \\
\hline & Total & 3 & $1.89 \%$ \\
\hline \multirow{7}{*}{$\begin{array}{l}\text { Large breeds } \\
22-45 \mathrm{~kg}\end{array}$} & German Shepherd & 62 & $5.19 \%$ \\
\hline & Golden Retriever & 36 & $5.36 \%$ \\
\hline & German Rottweiler & 18 & $3.90 \%$ \\
\hline & Labrador Retriever & 5 & $2.96 \%$ \\
\hline & Siberian Husky & 7 & $5.56 \%$ \\
\hline & Alaskan Husky & 3 & $3.26 \%$ \\
\hline & Total & 131 & $4.83 \%$ \\
\hline \multirow{4}{*}{$\begin{array}{l}\text { Medium } \\
\text { breeds12-22kg }\end{array}$} & American Pitbull & 4 & $1.28 \%$ \\
\hline & Mongrel (Mixed-breed) & 163 & $61.74 \%$ \\
\hline & Doberman Pinscher & 1 & $2.04 \%$ \\
\hline & Total & 168 & $26.84 \%$ \\
\hline \multirow{5}{*}{$\begin{array}{l}\text { Small breeds } 5 \text { - } \\
12 \mathrm{~kg}\end{array}$} & Grand Griffon Vendèen & 7 & $3.26 \%$ \\
\hline & Petit Basset Griffon Vendèen & 2 & $1.36 \%$ \\
\hline & English Cocker Spaniel & 3 & $2.97 \%$ \\
\hline & American Cocker Spaniel & 2 & $4.08 \%$ \\
\hline & Total & 14 & $2.73 \%$ \\
\hline \multirow{4}{*}{$\begin{array}{l}\text { Mini breeds less } \\
\text { than } 5 \mathrm{~kg}\end{array}$} & Yorkshire Terrier & 2 & $7.41 \%$ \\
\hline & Pomeranian & 4 & $22.22 \%$ \\
\hline & Chihuahua & 2 & $13.33 \%$ \\
\hline & Total & 8 & $13.33 \%$ \\
\hline \multicolumn{2}{|l|}{ Total } & 324 & $7.96 \%$ \\
\hline
\end{tabular}

Table 6. Incidence of the fracture among affected cat breeds (Classified according to the body conformation).

\section{Cat breeds}

Fracture cases
The percentage from admitted breed

\begin{tabular}{|c|c|c|c|}
\hline \multirow{3}{*}{ Cobby } & Persian & 54 & $1.99 \%$ \\
\hline & Himalayan & 3 & $1.85 \%$ \\
\hline & Total & 57 & $1.98 \%$ \\
\hline \multirow{2}{*}{ Moderate } & Mongrel & 87 & $14.01 \%$ \\
\hline & Total & 87 & $14.01 \%$ \\
\hline \multirow{3}{*}{ Svelte } & Siamese & 4 & $3.17 \%$ \\
\hline & Egyptian Mau & 1 & $1.47 \%$ \\
\hline & Total & 5 & $2.58 \%$ \\
\hline \multicolumn{2}{|c|}{ Total } & 149 & $4.04 \%$ \\
\hline
\end{tabular}

Table 7. Incidence of the fracture among affected dogs and cats (Classified according to the gender)

\begin{tabular}{|c|c|c|c|c|c|c|c|}
\hline \multirow{2}{*}{ Species } & & \multicolumn{3}{|c|}{ Fracture cases } & \multicolumn{3}{|c|}{ Total admitted cases } \\
\hline & & Male & Female & Total & Male & Female & Total \\
\hline \multirow{4}{*}{ Dog } & No. & 212 & 112 & 324 & 2784 & 1841 & 4625 \\
\hline & $\%$ out of total fracture cases & $65.43 \%$ & $34.57 \%$ & $100.00 \%$ & & & \\
\hline & $\%$ out of total admitted related gender & $7.61 \%$ & $6.08 \%$ & $7.01 \%$ & & & \\
\hline & $\%$ out of total admitted cases & $4.58 \%$ & $2.42 \%$ & $7.01 \%$ & $60.19 \%$ & $39.81 \%$ & $100.00 \%$ \\
\hline \multirow{4}{*}{ Cat } & No. & 99 & 50 & 149 & 1454 & 2258 & 3712 \\
\hline & $\%$ out of total fracture cases & $66.44 \%$ & $33.56 \%$ & $100.00 \%$ & & & \\
\hline & $\%$ out of total admitted related gender & $6.81 \%$ & $2.21 \%$ & $4.01 \%$ & & & \\
\hline & $\%$ out of total admitted cases & $2.67 \%$ & $1.35 \%$ & $4.01 \%$ & $39.17 \%$ & $60.83 \%$ & $100.00 \%$ \\
\hline \multirow{4}{*}{ Total } & No. & 311 & 162 & 473 & 4238 & 4099 & 8337 \\
\hline & $\%$ out of total fracture cases & $65.75 \%$ & $34.25 \%$ & $100.00 \%$ & & & \\
\hline & $\%$ out of total admitted related gender & $7.34 \%$ & $3.95 \%$ & $5.67 \%$ & & & \\
\hline & $\%$ out of total admitted cases & $3.73 \%$ & $1.94 \%$ & $5.67 \%$ & $50.83 \%$ & $49.17 \%$ & $100.00 \%$ \\
\hline
\end{tabular}


Table 8. The incidence of the fracture among the affected dogs and cats (Classified according to the age).

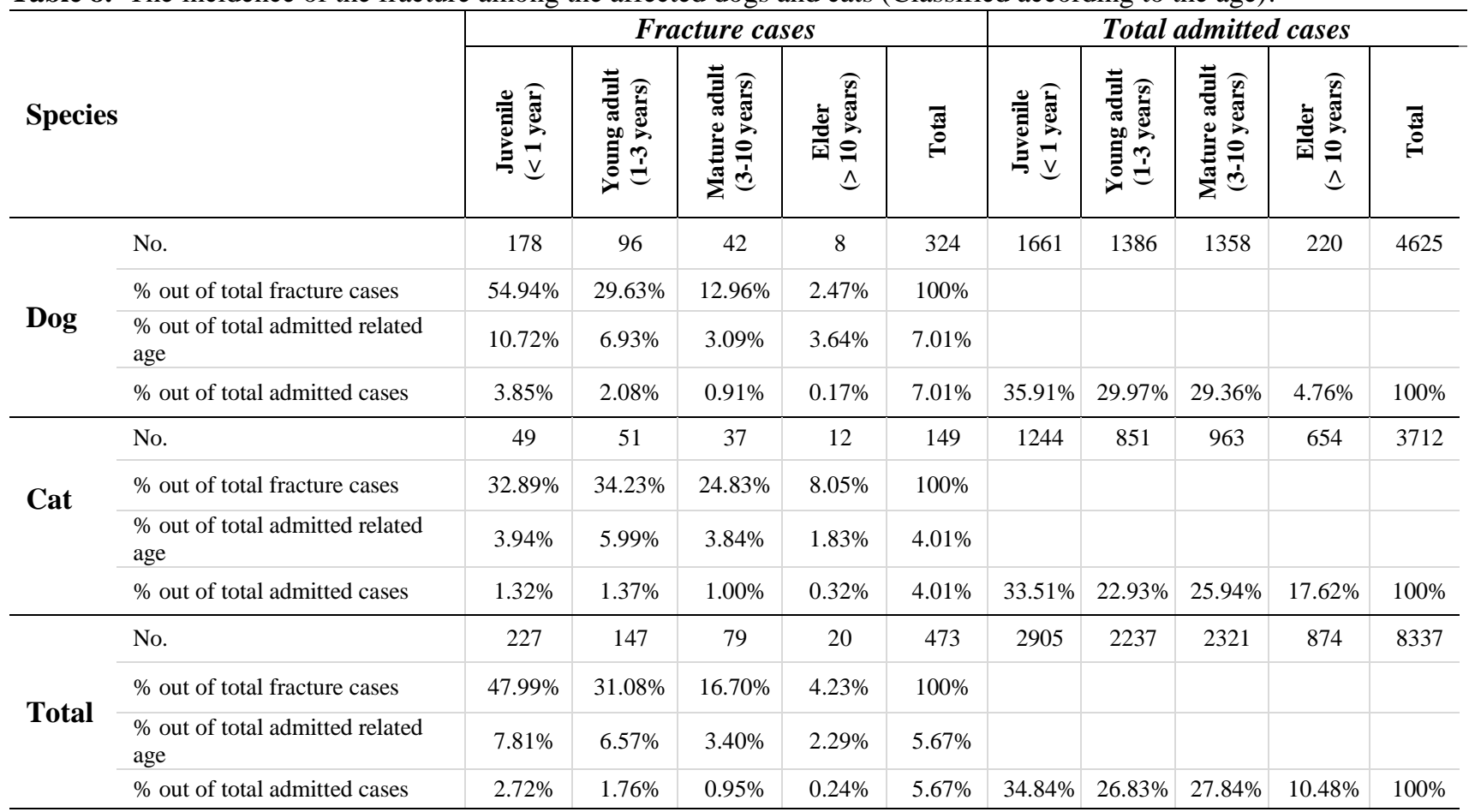

Table 9. The causes of fracture among the affected dogs and cats cases admitted to the Referral Veterinary Teaching Hospital, Cairo University and some Private Clinics in Egypt from January 2017 to January 2020.

\begin{tabular}{|c|c|c|c|c|c|c|c|c|}
\hline \multirow[b]{2}{*}{ Species } & \multicolumn{8}{|c|}{ Cause of fracture } \\
\hline & $\begin{array}{c}\text { Road } \\
\text { traffic } \\
\text { accident }\end{array}$ & $\begin{array}{c}\text { Fall from } \\
\text { height }\end{array}$ & $\begin{array}{l}\text { Unknown } \\
\text { cause }\end{array}$ & $\begin{array}{l}\text { Indoor } \\
\text { trauma }\end{array}$ & $\begin{array}{l}\text { Pathologica } \\
\text { l conditions }\end{array}$ & Animal bite & $\begin{array}{c}\text { Human } \\
\text { abuse }\end{array}$ & Total \\
\hline \multirow{2}{*}{ Dog } & 141 & 63 & 71 & 18 & 12 & 10 & 9 & 324 \\
\hline & $43.5 \%$ & $19.4 \%$ & $21.9 \%$ & $5.6 \%$ & $3.7 \%$ & $3.1 \%$ & $2.8 \%$ & $100 \%$ \\
\hline \multirow{2}{*}{ Cat } & 74 & 54 & 11 & 8 & 2 & 0 & 0 & 149 \\
\hline & $49.7 \%$ & $36.2 \%$ & $7.4 \%$ & $5.4 \%$ & $1.3 \%$ & $0 \%$ & $0 \%$ & $100 \%$ \\
\hline \multirow{2}{*}{ Total } & 215 & 117 & 82 & 26 & 14 & 10 & 9 & 473 \\
\hline & $45.5 \%$ & $24.7 \%$ & $17.3 \%$ & $5.5 \%$ & $3 \%$ & $2.1 \%$ & $1.9 \%$ & $100 \%$ \\
\hline
\end{tabular}

Table 10. The incidence of fracture among the affected dogs and cats cases admitted to the Referral Veterinary Teaching Hospital, Cairo University and some Private Clinics in Egypt from January 2017 to January 2020 (Classified according to the affected skeletal part of the body).

\begin{tabular}{|c|c|c|c|c|c|c|c|}
\hline \multirow{3}{*}{ Species } & \multicolumn{3}{|c|}{ The affected skeletal part } & & & & \multirow{3}{*}{$\begin{array}{c}\text { Total } \\
\text { fracture } \\
\text { cases }\end{array}$} \\
\hline & \multicolumn{3}{|c|}{ Axial skeleton } & \multicolumn{3}{|c|}{ Appendicular skeleton } & \\
\hline & $\begin{array}{c}\text { Skull / } \\
\text { Mandible }\end{array}$ & $\begin{array}{c}\text { Vertebrae / } \\
\text { ribs }\end{array}$ & Total & Forelimb & Hindlimb & Total & \\
\hline \multirow{2}{*}{ Dog } & 13 & 29 & 42 & 88 & 194 & 282 & 324 \\
\hline & $4 \%$ & $9 \%$ & $13 \%$ & $27 \%$ & $60 \%$ & $87 \%$ & $100 \%$ \\
\hline \multirow{2}{*}{ Cat } & 31 & 11 & 42 & 30 & 77 & 107 & 149 \\
\hline & $20.8 \%$ & $7.4 \%$ & $28.2 \%$ & $20.1 \%$ & $51.7 \%$ & $71.8 \%$ & $100 \%$ \\
\hline \multirow{2}{*}{ Total } & 44 & 40 & 84 & 118 & 271 & 389 & 473 \\
\hline & $9.3 \%$ & $8.5 \%$ & $17.8 \%$ & $25 \%$ & $57.2 \%$ & $82.2 \%$ & $100 \%$ \\
\hline
\end{tabular}

Table 11. Distribution of fractures in different appendicular bones in dogs' and cats' cases admitted to the Referral Veterinary Teaching Hospital, Cairo University and some Private Clinics in Egypt from January 2017 to January 2020.

\begin{tabular}{|c|c|c|c|c|c|c|}
\hline \multirow{2}{*}{ Species } & \multicolumn{6}{|c|}{ Appendicular bone } \\
\hline & Femur & Tibia \& Fibula & Humerus & Radius \& Ulna & Other bones & Total \\
\hline \multirow{2}{*}{ Dog } & 108 & 63 & 14 & 52 & 45 & 282 \\
\hline & $38.3 \%$ & $22.3 \%$ & $5 \%$ & $18.4 \%$ & $16 \%$ & $100 \%$ \\
\hline \multirow{2}{*}{ Cat } & 46 & 20 & 14 & 6 & 21 & 107 \\
\hline & $43 \%$ & $18.7 \%$ & $13.1 \%$ & $5.6 \%$ & $19.6 \%$ & $100 \%$ \\
\hline \multirow{2}{*}{ Total } & 154 & 83 & 28 & 58 & 66 & 389 \\
\hline & $39.6 \%$ & 21.3 & $7.2 \%$ & $14.9 \%$ & $17 \%$ & $100 \%$ \\
\hline
\end{tabular}


Establishment of the types and frequency of the bone fractures' occurrence

Classification of bone fractures based on the body parts, the incidence of specific limb and specific bone fractures

According to the affected skeletal part (table 10), the incidence of fracture among the affected dogs and cats were recorded as axial fractures (42 dogs, $13 \%$ and 42 cats, 28.2\%) and appendicular fractures (282 dogs, $87 \%$ and 107 cats, $71.8 \%$ ).

Incidence of specific limb (forelimbs / hind limbs) fractures.

Incidence of the fractures was found predominantly in hind limbs in dogs and cats, as 60\% (n: 194) in dogs and $51.7 \%$ (n: 77 ) in cats. In turn, $27 \%$ (n: 88 ) of the fractures occurred in the forelimbs in dogs and $20.1 \%$ (n: 30 ) in cats (Table 10).

\section{Incidence of specific appendicular bone fractures.}

Concerning both forelimbs and hind limbs, in dogs, femur was the most affected bone (38.3\%, n: 108), followed by the tibia/fibula $(22.3 \%, \mathrm{n}: 63)$, radius/ulna $(18.4 \%$, n: 52$)$ and humerus $(5 \%, \mathrm{n}: 14)$. Meanwhile in cats, femur was the most affected bone (43\%, n: 46$)$, followed by the tibia/fibula (18.7\%, n: 20$)$, humerus (13.1\%, n: 14$)$ and radius/ulna (5.6\%, n: 6) (Table 11).

Frequency of the different types of appendicular bone fracture based on the extent of tissue damage, site, and shape of the fracture line

The extent of tissue damage

Open or closed fracture. In the present study, closed fractures were more frequently recorded in dogs $(89 \%, \mathrm{n}$ : $282)$ and cats $(76.6 \% \mathrm{n}: 82)$ than open fractures (11\%, n: 31$)$ in dogs and (23.4\% n: 25) in cats (Table 12). Regarding the forelimb (118 cases; 88 dogs and 30 cats), closed fractures (96 cases; 69 dogs and 27 cats) were recorded in 14, 40, and 15 dogs and 14,3 , and 10 cats in the humerus, radius \& ulna and other bones representing $100 \%, 76.9 \%$ and $68.2 \%$ in dogs and $100 \%, 50 \%$ and $100 \%$ in cats out of the related bone fracture cases respectively, while open fractures (22 cases; 19 dogs and 3 cats) were recorded in 0,12 , and seven dogs and 0 , three, and 0 cats in the humerus, radius \& ulna and other bones representing $0 \%, 23.1 \%$ and $31.8 \%$ in dogs and $0 \%, 50 \%$ and $0 \%$ in cats out of the related bone fracture cases respectively. Regarding hindlimb (271 cases; 194 dogs and 77 cats), closed fractures ( 237 cases; 182 dogs and 55 cats) were recorded in 102, 57, and 23 dogs, and 30, 14, and 11 cats in the femur, tibia \& fibula and other bones representing $94.4 \%, 90.5 \%$ and $100 \%$ in dogs and $65.2 \%, 70 \%$ and $100 \%$ in cats out of the related bone fracture cases respectively, while open fractures ( 34 cases; 12 dogs and 22 cats) were recorded in the femur, tibia \& fibula and other bones representing $5.6 \%, 9.5 \%$ and $0 \%$ in dogs and $34.8 \%, 30 \%$ and $0 \%$ in cats out of the related bone (femur, tibia \& fibula and other bones) fracture cases respectively.

Incomplete or complete fracture. The obtained results revealed that incomplete fractures were recorded in $42 \mathrm{dogs}$ and three representing $17.7 \%$ and $3.5 \%$ out of total fore and hind limbs long bone fractures (femur, tibia NS fibula, humerus and radius and ulna), while complete fractures were recorded in 195 dogs and 83 cats representing $82.3 \%$ and 96.5\% out of total fore and hind limbs long bone fractures (femur, tibia and fibula, humerus and radius and ulna) (Tables 13 and 14).

\section{Fractures'location}

Proximal, diaphyseal or distal zones. Regarding the location of the fracture among the affected long bones, proximal, diaphyseal, and distal fractures were recorded in 27, 156 and 54 cases in dogs and 13,37, and 36 cases in cats representing $11.4 \%, 65.8 \%$, and $22.8 \%$, and $15.1 \%, 43 \%$, and $41.9 \%$ out of total fore and hind limbs long bone fractures (femur, tibia and fibula, humerus, and radius and ulna) in dogs and cats respectively (Tables 13 and 14).

\section{Fractures' line}

The number of fractures' line (single or comminuted). Regarding the number of the fractures' line among the affected long bones, single and comminuted fractures were recorded in 151 and $44 \mathrm{dogs}$, and 76 and 7 cats representing $63.7 \%$ and $18.6 \%$, and $88.4 \%$ and $8.1 \%$ out of total fore and hind limbs long bone fractures (femur, tibia \& fibula, humerus, and radius \& ulna) in dogs and cats respectively (Tables 13 and 14).

The direction of fractures' line (transverse, oblique or spiral). Regarding the location of the fracture among the affected long bones, transverse, oblique, or spiral fractures were recorded in 75, 56, and 20 dogs, and 41, 24, and 11 cats representing $31.7 \%, 23.6 \%$, and $8.4 \%$, and $47.7 \%, 27.9 \%$, and $12.8 \%$ out of total fore and hind limbs long bone fractures (femur, tibia \& fibula, humerus, and radius \& ulna) in dogs and cats respectively (Tables 13 and 14). 
Table 12. Incidinces of the different types of appendicular bone fracture in dogs' and cats' cases admitted to the Referral Veterinary Teaching Hospital, Cairo University and some Private Clinics in Egypt from January 2017 to January 2020 based on the extent of tissue damage.

\begin{tabular}{|c|c|c|c|c|c|c|c|c|c|c|}
\hline \multirow[b]{2}{*}{ Species } & \multirow[b]{2}{*}{ Fracture } & \multicolumn{4}{|c|}{ Forelimb } & \multicolumn{4}{|c|}{ Hindlimb } & \multirow[b]{2}{*}{ Total } \\
\hline & & Humerus & $\begin{array}{c}\text { Radius \& } \\
\text { Ulna }\end{array}$ & $\begin{array}{l}\text { Other } \\
\text { bones }\end{array}$ & Total & Femur & $\begin{array}{c}\text { Tibia \& } \\
\text { Fibula }\end{array}$ & $\begin{array}{l}\text { Other } \\
\text { bones }\end{array}$ & Total & \\
\hline \multirow{6}{*}{ Dog } & \multirow[b]{2}{*}{ Open } & 0 & 12 & 7 & 19 & 6 & 6 & 0 & 12 & 31 \\
\hline & & $\begin{array}{c}0 \% \\
(0 \%)\end{array}$ & $\begin{array}{c}38.7 \% \\
(23.1 \%)\end{array}$ & $\begin{array}{c}22.6 \% \\
(31.8 \%)\end{array}$ & $\begin{array}{c}61.3 \% \\
(21.6 \%)\end{array}$ & $\begin{array}{l}19.4 \% \\
(5.6 \%)\end{array}$ & $\begin{array}{l}19.4 \% \\
(9.5 \%)\end{array}$ & $\begin{array}{c}0 \% \\
(0 \%)\end{array}$ & $\begin{array}{l}38.7 \% \\
(6.2 \%)\end{array}$ & $\begin{array}{l}100 \% \\
(11 \%)\end{array}$ \\
\hline & \multirow[b]{2}{*}{ Closed } & 14 & 40 & 15 & 69 & 102 & 57 & 23 & 182 & 251 \\
\hline & & $\begin{array}{c}5.6 \% \\
(100 \%)\end{array}$ & $\begin{array}{c}15.9 \% \\
(76.9 \%)\end{array}$ & $\begin{array}{c}6 \% \\
(68.2 \%)\end{array}$ & $\begin{array}{c}27.5 \% \\
(78.4 \%)\end{array}$ & $\begin{array}{c}40.6 \% \\
(94.4 \%)\end{array}$ & $\begin{array}{c}22.7 \% \\
(90.5 \%)\end{array}$ & $\begin{array}{c}9.2 \% \\
(100 \%)\end{array}$ & $\begin{array}{c}72.5 \% \\
(93.8 \%)\end{array}$ & $\begin{array}{l}100 \% \\
(89 \%)\end{array}$ \\
\hline & \multirow[b]{2}{*}{ Total } & 14 & 52 & 22 & 88 & 108 & 63 & 23 & 194 & 282 \\
\hline & & $\begin{array}{c}5 \% \\
(100 \%)\end{array}$ & $\begin{array}{l}18.4 \% \\
(100 \%)\end{array}$ & $\begin{array}{c}7.8 \% \\
(100 \%)\end{array}$ & $\begin{array}{c}31.2 \% \\
(100 \%)\end{array}$ & $\begin{array}{l}38.3 \% \\
(100 \%)\end{array}$ & $\begin{array}{l}22.3 \% \\
(100 \%)\end{array}$ & $\begin{array}{c}8.2 \% \\
(100 \%)\end{array}$ & $\begin{array}{c}68.8 \% \\
(100 \%)\end{array}$ & $\begin{array}{c}100 \% \\
(100 \%)\end{array}$ \\
\hline \multirow{6}{*}{ Cat } & \multirow[b]{2}{*}{ Open } & 0 & 3 & 0 & 3 & 16 & 6 & 0 & 22 & 25 \\
\hline & & $\begin{array}{c}0 \% \\
(0 \%)\end{array}$ & $\begin{array}{c}12 \% \\
(50 \%)\end{array}$ & $\begin{array}{c}0 \% \\
(0 \%)\end{array}$ & $\begin{array}{c}12 \% \\
(10 \%)\end{array}$ & $\begin{array}{c}64 \% \\
(34.8 \%)\end{array}$ & $\begin{array}{c}24 \% \\
(30 \%)\end{array}$ & $\begin{array}{c}0 \% \\
(0 \%)\end{array}$ & $\begin{array}{c}88 \% \\
(28.6 \%)\end{array}$ & $\begin{array}{c}100 \% \\
(23.4 \%)\end{array}$ \\
\hline & \multirow[b]{2}{*}{ Closed } & 14 & 3 & 10 & 27 & 30 & 14 & 11 & 55 & 82 \\
\hline & & $\begin{array}{c}17.1 \% \\
(100 \%)\end{array}$ & $\begin{array}{l}3.7 \% \\
(50 \%)\end{array}$ & $\begin{array}{c}12.2 \% \\
(100 \%)\end{array}$ & $\begin{array}{l}32.9 \% \\
(90 \%)\end{array}$ & $\begin{array}{c}36.6 \% \\
(65.2 \%)\end{array}$ & $\begin{array}{l}17.1 \% \\
(70 \%)\end{array}$ & $\begin{array}{c}13.4 \% \\
(100 \%)\end{array}$ & $\begin{array}{c}67.1 \% \\
(71.4 \%)\end{array}$ & $\begin{array}{c}100 \% \\
(76.6 \%)\end{array}$ \\
\hline & \multirow[b]{2}{*}{ Total } & 14 & 6 & 10 & 30 & 46 & 20 & 11 & 77 & 107 \\
\hline & & $\begin{array}{c}13.1 \% \\
(100 \%)\end{array}$ & $\begin{array}{c}5.6 \% \\
(100 \%)\end{array}$ & $\begin{array}{c}9.3 \% \\
(100 \%)\end{array}$ & $\begin{array}{c}28 \% \\
(100 \%)\end{array}$ & $\begin{array}{c}43 \% \\
(100 \%)\end{array}$ & $\begin{array}{l}18.7 \% \\
(100 \%)\end{array}$ & $\begin{array}{c}10.3 \% \\
(100 \%)\end{array}$ & $\begin{array}{c}72 \% \\
(100 \%)\end{array}$ & $\begin{array}{c}100 \% \\
(100 \%)\end{array}$ \\
\hline \multirow{6}{*}{ Total } & \multirow[b]{2}{*}{ Open } & 0 & 15 & 7 & 22 & 22 & 12 & 0 & 34 & 56 \\
\hline & & $\begin{array}{c}0 \% \\
(0 \%)\end{array}$ & $\begin{array}{l}26.8 \% \\
(25.9 \%)\end{array}$ & $\begin{array}{c}12.5 \% \\
(21.9 \%)\end{array}$ & $\begin{array}{c}39.3 \% \\
(18.6 \%)\end{array}$ & $\begin{array}{c}39.3 \% \\
(14.3 \%)\end{array}$ & $\begin{array}{c}21.4 \% \\
(14.5 \%)\end{array}$ & $\begin{array}{c}0 \% \\
(0 \%)\end{array}$ & $\begin{array}{l}60.7 \% \\
(12.5 \%)\end{array}$ & $\begin{array}{c}100 \% \\
(14.4 \%)\end{array}$ \\
\hline & \multirow[b]{2}{*}{ Closed } & 28 & 43 & 25 & 96 & 132 & 71 & 34 & 237 & 333 \\
\hline & & $\begin{array}{c}8.4 \% \\
(100 \%)\end{array}$ & $\begin{array}{c}12.9 \% \\
(74.1 \%)\end{array}$ & $\begin{array}{c}7.5 \% \\
(78.1 \%)\end{array}$ & $\begin{array}{c}28.8 \% \\
(81.4 \%)\end{array}$ & $\begin{array}{c}42.6 \% \\
(85.7 \%)\end{array}$ & $\begin{array}{c}21.3 \% \\
(85.5 \%)\end{array}$ & $\begin{array}{c}10.2 \% \\
(100 \%)\end{array}$ & $\begin{array}{l}71.1 \% \\
(87.5 \%)\end{array}$ & $\begin{array}{c}100 \% \\
(85.6 \%)\end{array}$ \\
\hline & \multirow[b]{2}{*}{ Total } & 28 & 58 & 32 & 118 & 154 & 83 & 34 & 271 & 389 \\
\hline & & $\begin{array}{c}7.2 \% \\
(100 \%)\end{array}$ & $\begin{array}{l}14.9 \% \\
(100 \%)\end{array}$ & $\begin{array}{c}8.2 \% \\
(100 \%)\end{array}$ & $\begin{array}{c}30.3 \% \\
(100 \%)\end{array}$ & $\begin{array}{c}39.6 \% \\
(100 \%)\end{array}$ & $\begin{array}{l}21.3 \% \\
(100 \%)\end{array}$ & $\begin{array}{c}8.7 \% \\
(100 \%)\end{array}$ & $\begin{array}{c}69.6 \% \\
(100 \%)\end{array}$ & $\begin{array}{c}100 \% \\
(100 \%)\end{array}$ \\
\hline
\end{tabular}

Table 13. Incidince of the different types of appendicular bone fracture in dogs' cases admitted to the Referral Veterinary Teaching Hospital, Cairo University and some Private Clinics in Egypt from January 2017 to January 2020 based on the extent, site, and shape of the fracture line.

\begin{tabular}{|c|c|c|c|c|c|c|c|}
\hline \multirow{2}{*}{\multicolumn{2}{|c|}{ Fracture type }} & \multirow{3}{*}{ Incomplete } & \multicolumn{4}{|c|}{ Complete } & \multirow{2}{*}{ Total } \\
\hline & & & \multicolumn{3}{|c|}{ Single } & \multirow[t]{2}{*}{ Comminuted } & \\
\hline Site & Bone & & Transverse & Oblique & Spiral & & \\
\hline \multirow{20}{*}{ Proximal } & Femur & 7 & 3 & - & - & - & 10 \\
\hline & & $70.0 \%$ & $30.0 \%$ & - & - & - & $100 \%$ \\
\hline & & $(43.8 \%)$ & $(37.5 \%)$ & - & - & - & $(37.0 \%)$ \\
\hline & & [16.7\%] & {$[4.0 \%]$} & - & - & - & {$[4.2 \%]$} \\
\hline & Tibia \& fibula & 9 & 3 & 3 & - & - & 15 \\
\hline & & $60.0 \%$ & $20.0 \%$ & $20.0 \%$ & - & - & $100 \%$ \\
\hline & & $(56.3 \%)$ & $(37.5 \%)$ & $(100 \%)$ & - & - & $(55.6 \%)$ \\
\hline & & [21.4\%] & {$[4.0 \%]$} & {$[5.4 \%]$} & - & - & [6.3\%] \\
\hline & Humerus & - & - & - & - & - & - \\
\hline & & - & - & - & - & - & - \\
\hline & & - & - & - & - & - & - \\
\hline & & - & - & - & - & - & - \\
\hline & Radius \& ulna & - & 2 & - & - & - & 2 \\
\hline & & - & $100 \%$ & - & - & - & $100 \%$ \\
\hline & & - & $(25.0 \%)$ & - & - & - & $(7.4 \%)$ \\
\hline & & - & {$[2.7 \%]$} & - & - & - & {$[0.8 \%]$} \\
\hline & Total & 16 & 8 & 3 & - & - & 27 \\
\hline & & $59.3 \%$ & $29.6 \%$ & $11.1 \%$ & - & - & $100 \%$ \\
\hline & & $(100 \%)$ & $(100 \%)$ & $(100 \%)$ & - & - & $(100 \%)$ \\
\hline & & [38.1\%] & [10.7\%] & [5.4\%] & - & - & [11.4\%] \\
\hline \multirow{17}{*}{ Diaphyseal } & Femur & 7 & 3 & 14 & 20 & 26 & 70 \\
\hline & & $10.0 \%$ & $4.3 \%$ & $20.0 \%$ & $28.6 \%$ & $37.1 \%$ & $100 \%$ \\
\hline & & $(29.2 \%)$ & $(8.6 \%)$ & $(35.0 \%)$ & $(100.0 \%)$ & $(70.3 \%)$ & $(44.9 \%)$ \\
\hline & & [16.7\%] & [4.0\%] & [25.0\%] & [100.0\%] & [59.1\%] & [29.5\%] \\
\hline & Tibia \& fibula & 3 & 13 & 18 & - & 7 & 41 \\
\hline & & $7.3 \%$ & $31.7 \%$ & $43.9 \%$ & - & $17.1 \%$ & $100 \%$ \\
\hline & & $(12.5 \%)$ & $(37.1 \%)$ & $(45.0 \%)$ & - & $(18.9 \%)$ & $(26.3 \%)$ \\
\hline & & {$[7.1 \%]$} & [17.3\%] & [32.1\%] & - & [15.9\%] & [17.3\%] \\
\hline & Humerus & 2 & 4 & - & - & 1 & 7 \\
\hline & & $28.6 \%$ & $57.1 \%$ & - & - & $14.3 \%$ & $100 \%$ \\
\hline & & $(8.3 \%)$ & (11.4\%) & - & - & $(2.7 \%)$ & $(4.5 \%)$ \\
\hline & & [4.8\%] & {$[5.3 \%]$} & - & - & [2.3\%] & {$[3.0 \%]$} \\
\hline & Radius \& ulna & 12 & 15 & 8 & - & 3 & 38 \\
\hline & & $31.6 \%$ & $39.5 \%$ & $21.1 \%$ & - & $7.9 \%$ & $100 \%$ \\
\hline & & $(50.0 \%)$ & $(42.9 \%)$ & $(20.0 \%)$ & - & $(8.1 \%)$ & $(24.4 \%)$ \\
\hline & & [28.6\%] & [20.0\%] & [14.3\%] & - & [6.8\%] & [16.0\%] \\
\hline & Total & 24 & 35 & 40 & 20 & 37 & 156 \\
\hline
\end{tabular}




\begin{tabular}{|c|c|c|c|c|c|c|c|}
\hline & & $\begin{array}{c}15.4 \% \\
(100 \%) \\
{[57.1 \%]} \\
\end{array}$ & $\begin{array}{l}22.4 \% \\
(100 \%) \\
{[46.7 \%]} \\
\end{array}$ & $\begin{array}{l}25.6 \% \\
(100 \%) \\
{[71.4 \%]} \\
\end{array}$ & $\begin{array}{c}12.8 \% \\
(100 \%) \\
{[100.0 \%]}\end{array}$ & $\begin{array}{l}23.7 \% \\
(100 \%) \\
{[84.1 \%]} \\
\end{array}$ & $\begin{array}{c}100 \% \\
(100 \%) \\
{[65.8 \%]}\end{array}$ \\
\hline \multirow{20}{*}{ Distal } & Femur & - & 19 & 4 & - & 5 & 28 \\
\hline & & - & $67.9 \%$ & $14.3 \%$ & - & $17.9 \%$ & $100 \%$ \\
\hline & & - & $(59.4 \%)$ & $(30.8 \%)$ & - & $(71.4 \%)$ & $(51.9 \%)$ \\
\hline & & - & {$[25.3 \%]$} & {$[7.1 \%]$} & - & {$[11.4 \%]$} & [11.8\%] \\
\hline & Tibia $\&$ fibula & - & 3 & 2 & - & 2 & 7 \\
\hline & & - & $42.9 \%$ & $28.6 \%$ & - & $28.6 \%$ & $100 \%$ \\
\hline & & - & $(9.4 \%)$ & $(15.4 \%)$ & - & $(28.6 \%)$ & $(13.0 \%)$ \\
\hline & & - & {$[4.0 \%]$} & {$[3.6 \%]$} & - & {$[4.5 \%]$} & {$[3.0 \%]$} \\
\hline & Humerus & - & 5 & 2 & - & - & 7 \\
\hline & & - & $71.4 \%$ & $28.6 \%$ & - & - & $100 \%$ \\
\hline & & - & $(15.6 \%)$ & $(15.4 \%)$ & - & - & $(13.0 \%)$ \\
\hline & & - & {$[6.7 \%]$} & {$[3.6 \%]$} & - & - & [3.0\%] \\
\hline & Radius \& ulna & 2 & 5 & 5 & - & - & 12 \\
\hline & & $16.7 \%$ & $41.7 \%$ & $41.7 \%$ & - & - & $100 \%$ \\
\hline & & $(100.0 \%)$ & $(15.6 \%)$ & $(38.5 \%)$ & - & - & $(22.2 \%)$ \\
\hline & & {$[4.8 \%]$} & {$[6.7 \%]$} & {$[8.9 \%]$} & - & - & {$[5.1 \%]$} \\
\hline & Total & 2 & 32 & 13 & - & 7 & 54 \\
\hline & & $3.7 \%$ & $59.3 \%$ & $24.1 \%$ & - & $13.0 \%$ & $100 \%$ \\
\hline & & $(100 \%)$ & $(100 \%)$ & $(100 \%)$ & - & $(100 \%)$ & $(100 \%)$ \\
\hline & & {$[4.8 \%]$} & [42.7\%] & {$[23.2 \%]$} & - & [15.9\%] & [22.8\%] \\
\hline \multirow[t]{3}{*}{ Total } & & 42 & 75 & 56 & 20 & 44 & 237 \\
\hline & & $17.7 \%$ & $31.7 \%$ & $23.6 \%$ & $8.4 \%$ & $18.6 \%$ & $100 \%$ \\
\hline & & {$[100 \%]$} & {$[100 \%]$} & {$[100 \%]$} & {$[100 \%]$} & {$[100 \%]$} & {$[100 \%]$} \\
\hline
\end{tabular}

Table 14. Incidince of the different types of appendicular bone fracture in cats' cases admitted to the Referral Veterinary Teaching Hospital, Cairo University and some Private Clinics in Egypt from January 2017 to January 2020 based on the site, extend and shape of the fracture line.

\begin{tabular}{|c|c|c|c|c|c|c|c|}
\hline \multirow{2}{*}{\multicolumn{2}{|c|}{ Fracture type }} & \multirow[t]{3}{*}{ Incomplete } & \multicolumn{4}{|c|}{ Complete } & \multirow[t]{3}{*}{ Total } \\
\hline & & & \multicolumn{3}{|c|}{ Single } & \multirow[t]{2}{*}{ Comminuted } & \\
\hline Site & Bone & & Transverse & Oblique & Spiral & & \\
\hline \multirow{20}{*}{ Proximal } & Femur & 1 & 5 & 6 & - & - & 12 \\
\hline & & $8.3 \%$ & $41.7 \%$ & $50 \%$ & - & - & $100 \%$ \\
\hline & & $(100 \%)$ & $(83.3 \%)$ & $(100 \%)$ & - & - & $(92.3 \%)$ \\
\hline & & [33.3\%] & [12.2\%] & {$[25 \%]$} & - & - & {$[14 \%]$} \\
\hline & Tibia $\&$ fibula & - & - & - & - & - & - \\
\hline & & - & - & - & - & - & - \\
\hline & & - & - & - & - & - & - \\
\hline & & - & - & - & - & - & - \\
\hline & Humerus & - & - & - & - & - & - \\
\hline & & - & - & - & - & - & - \\
\hline & & - & - & - & - & - & - \\
\hline & & - & - & - & - & - & - \\
\hline & Radius \& ulna & - & 1 & - & - & - & 1 \\
\hline & & - & $100 \%$ & - & - & - & $100 \%$ \\
\hline & & - & $(16.7 \%)$ & - & - & - & $(7.7 \%)$ \\
\hline & & - & {$[2.4 \%]$} & - & - & - & {$[1.2 \%]$} \\
\hline & Total & 1 & 6 & 6 & - & - & 13 \\
\hline & & $7.7 \%$ & $46.2 \%$ & $46.2 \%$ & - & - & $100 \%$ \\
\hline & & $(100 \%)$ & $(100 \%)$ & $(100 \%)$ & - & - & $(100 \%)$ \\
\hline & & [33.3\%] & [14.6\%] & {$[25 \%]$} & - & - & [15.1\%] \\
\hline \multirow{20}{*}{ Diaphyseal } & Femur & - & 1 & 3 & 6 & 2 & 12 \\
\hline & & - & $8.3 \%$ & $25 \%$ & $50 \%$ & $16.7 \%$ & $100 \%$ \\
\hline & & - & $(20 \%)$ & $(21.4 \%)$ & $(54.5 \%)$ & $(33.3 \%)$ & $(32.4 \%)$ \\
\hline & & - & {$[2.4 \%]$} & {$[12.5 \%]$} & [54.5\%] & [28.6\%] & [14\%] \\
\hline & Tibia \& fibula & 1 & 1 & 8 & - & 4 & 14 \\
\hline & & $7.1 \%$ & $7.1 \%$ & $57.1 \%$ & - & $28.6 \%$ & $100 \%$ \\
\hline & & $(100 \%)$ & $(20 \%)$ & $(57.1 \%)$ & - & $(66.7 \%)$ & $(37.8 \%)$ \\
\hline & & [33.3\%] & {$[2.4 \%]$} & [33.3\%] & - & [57.1\%] & [16.3\%] \\
\hline & Humerus & - & 3 & 2 & 5 & - & 10 \\
\hline & & - & $30 \%$ & $20 \%$ & $50 \%$ & - & $100 \%$ \\
\hline & & - & $(60 \%)$ & $(14.3 \%)$ & $(54.5 \%)$ & - & $(27 \%)$ \\
\hline & & - & {$[7.3 \%]$} & {$[8.3 \%]$} & [54.5\%] & - & [11.6\%] \\
\hline & Radius \& ulna & - & - & 1 & - & - & 1 \\
\hline & & - & - & $100 \%$ & - & - & $100 \%$ \\
\hline & & - & - & $(7.1 \%)$ & - & - & $(2.7 \%)$ \\
\hline & & - & - & {$[4.2 \%]$} & - & - & [1.2\%] \\
\hline & Total & 1 & 5 & 14 & 11 & 6 & 37 \\
\hline & & $2.7 \%$ & $13.5 \%$ & $37.8 \%$ & $29.7 \%$ & $12.2 \%$ & $100 \%$ \\
\hline & & $(100 \%)$ & $(100 \%)$ & $(100 \%)$ & $(100 \%)$ & $(100 \%)$ & $(100 \%)$ \\
\hline & & [33.3\%] & [12.2\%] & [58.3\%] & [100\%] & {$[85.7 \%]$} & [43\%] \\
\hline \multirow{4}{*}{ Distal } & Femur & - & 21 & - & - & 1 & 22 \\
\hline & & - & $95.5 \%$ & - & - & $4.5 \%$ & $100 \%$ \\
\hline & & - & $(70 \%)$ & - & - & $(100 \%)$ & $(61.1 \%)$ \\
\hline & & - & [51.2\%] & - & - & [14.3\%] & {$[25.6 \%]$} \\
\hline
\end{tabular}




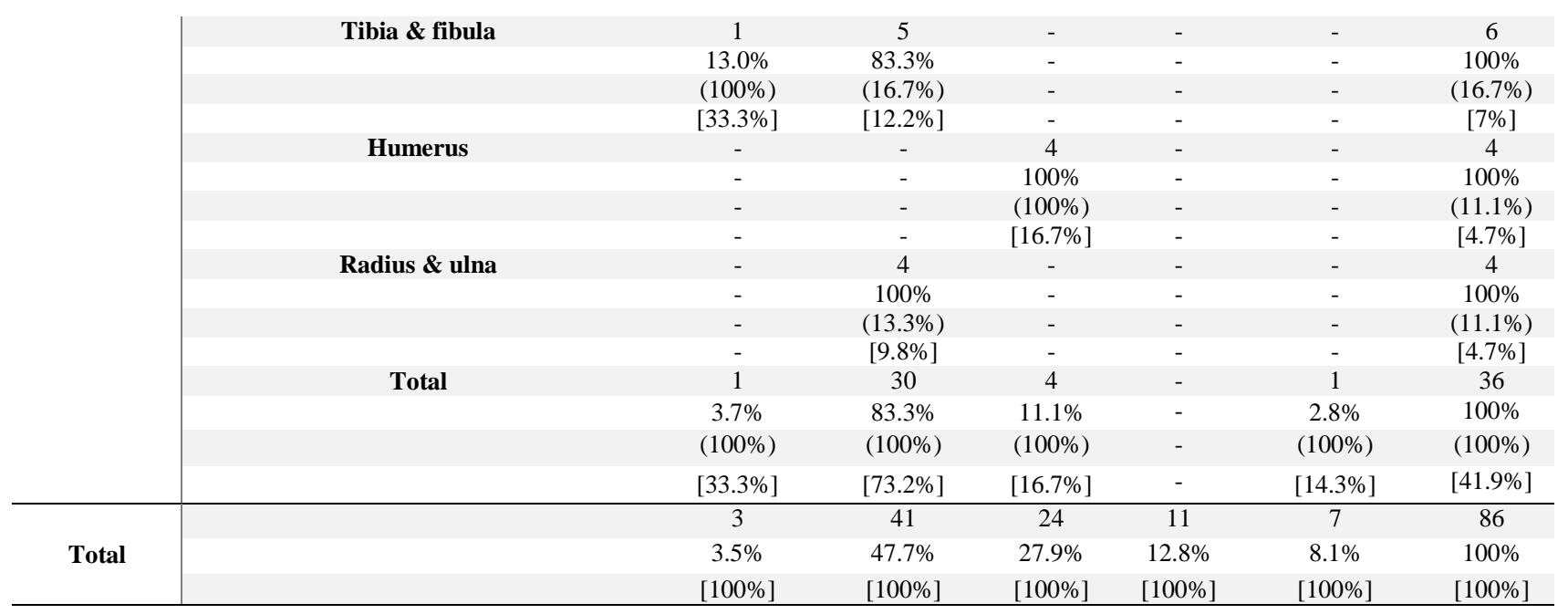

\section{DISCUSSION}

The present retrospective study provided novel descriptive data of the prevalence of dogs and cats with appendicular fractures in Egypt through the recorded cases in the referral veterinary teaching hospital, faculty of veterinary medicine, Cairo University and some private pet clinics in Cairo district, Egypt admitted from January 2017 to January 2020, and it emphasized the information that characterized the population (breed, age, gender and animal size).

The total number of the admitted cases to the hospital and the clinics during the current study period was 8337 pets (4625 dogs and 3712 cats) with a ratio of $55.5 \%$ to $44.5 \%$ respectively, which indicated that dog breeding is relatively more popular in the Egyptian society than raising cats. This may be due to the expansion of new communities with increasing numbers of compounds, resorts and villas in the regions with high social level which requires breeding guard dogs. This was clearly shown by the current findings that the most common admitted breeds were guard or outdoor dogs' breeds representing $68.8 \%$ of total admitted dogs. The results of the most common dog breeds in Egypt were in agreement with previous studies (Nouh et al., 2014; Rakha et al., 2015). More than the quarter of the admitted dogs was German Shepherd (25.8\%). On the other hand, mongrel or stray dogs (representing 5.7\% of total admitted dogs) were frequently admitted to the referral veterinary teaching hospital, faculty of veterinary medicine, Cairo university, through animal welfare societies and stray animal rescue persons or associations, and most of these cases were surgical injuries (representing $89 \%$ of total admitted mongrel dogs) with fracture incidence of $61.7 \%$.

Regarding the cat breeds, relatively, there were few different breeds raised within the Egyptian society. The results were nearly similar to previously recorded ones (Farghali et al., 2020). Only six cat breeds were admitted to the hospital and the clinics during the study period with the highest admission of Persian cat breed (representing $73.1 \%$ of total admitted cats). On the other hand, mongrel cats (representing $16.7 \%$ of total admitted cats) were frequently admitted to the referral veterinary teaching hospital, faculty of veterinary medicine, Cairo university. Some of them were raised indoor, and the others were presented through animal welfare societies and stray animal rescue associations or persons, and most of these cases were surgical injuries (representing $64.7 \%$ of total admitted mongrel cats) with soft tissue surgical affections and fracture incidences $(50.7 \%$ and $14 \%$ respectively).

In the present study, the incidence of fracture was higher in dogs $(7 \%)$ than in cats $(4 \%)$. Meanwhile, fractures observed in cats showed a similarity to those in dogs as in regard to the site of fracture. However, cats do have several advantages as orthopedic patients when compared to dogs including their light weight, straight bones, and anatomical configuration (Harasen, 2009; Singh et al., 2015). The highest incidences of the fracture cases were recorded in mongrel dogs and cats which may be due to the frequent exposure of stray animals to road traffic accidents. This result was similar to the previous study of Harasen 2003a (2004), Senn et al. (2004) and Uwagie-Ero et al. (2018).

With excluding of mongrel dogs (as anomalous fractures' incidence), the highest incidence of canine fracture cases was recorded in miniature breeds (less than $5 \mathrm{~kg}, 13.33 \%$ ), followed by large breeds (22-45 kg, $4.83 \%$ ), small breeds (5$12 \mathrm{~kg}, 2.73 \%$ ), giant breeds (over $45 \mathrm{~kg}, 1.89 \%$ ) and medium breeds $(12-22 \mathrm{~kg}, 1.4 \%)$. These results were nearly similar to those recorded in previous studies where the most commonly affected breed was Yorkshire terrier (12\%), followed by Poodle (12\%) and Maltese (9\%) (Minar et al., 2013). On the other side, some other previous studies have reported that German shepherds were the most affected breed (Ali, 2013; Rhangani, 2014; Libardni et al., 2016). Obviously, the variation of incidence of bone fractures in different breeds of dogs may be related to the regions/countries that the owners lived which may be different in behavior/life styles in the different countries (Minar et al., 2013). Other author mentioned that the size of the dog does not mean a condition of predisposition to fractures (Johnson, 2013). Many 
articles supported the theory that fractures were more often in smaller dogs (Brianza et al., 2006; Yu et al., 2010; De Arburn Parent et al., 2017). This may be due to the low muscle coverage in the limbs (Milovancev and Ralphs, 2004).

In cats, the highest incidence of bone fractures was recorded in mongrel breeds (14\%). This was similar to previous study by Borges et al. (2016). Other factor contributing in the high incidence of fractures in mongrel cat breed rather than the road traffic accidents of stray cats, was the fact that the majority of cats recorded in the clinic were mixed breed. Regarding cat's body conformation, the highest incidence was recorded in moderate (14.01\%) (Due to mongrel cats), followed by svelte $(2.58 \%)$ and cobby $(1.98 \%)$ breeds. It may be due to the normal playful behavior of svelte and moderate breeds with long limbs (Siamese and Egyptian Mau) resulting in frequent trauma and falling from a height more than the lazy cobby breeds with short limbs (Persian and Himalayan) (Helgren, 2013).

From the obtained data, male dogs $(60.19 \%)$ were more frequently admitted than female ones $(39.81 \%)$, while the opposite was recorded in cats $(39.17 \%$ male and $60.83 \%$ female). These findings may be screening the fact of preferring of dog owners to rear male dogs more than females. The result which barrels to other previous researches which added that male dogs are more sociable, dominant, territorial, playful, active, and independent than females (Hart and Hart, 2016; Scandurra et al., 2018). On the other hand, most of cat owners prefer to raise female cats more than males (as it is obvious in this work where queens were admitted about one and half times more than tomcats), may be due to the disliked behavior of much more territorial male cats during the mating season, such as spraying which is not desired by many of the owners (Farghali et al., 2020).

In the current study, gender was among the predisposing factors where remarkable higher incidence was recorded in male dogs $(65.4 \%)$ and cats $(66.4 \%)$, than females $(34.6 \%$ and $33.6 \%)$, respectively which is nearly the same in both species. This finding was similar to the reports elsewhere (Dvorak et al., 2000; Senn et al., 2004; Rhangani, 2014). As males are known to be more aggressive, and tend to roam for longer distances, it exposes them to external etiological agents (Simpson, 2004; Kumar et al., 2007; Ben Ali, 2013; Elzomor et al., 2014). Other factors, which may be incriminated, were escaping of uncastrated tomcat from homes during the mating season and exposure to falls from windows and road accidents (Farghali et al., 2020).

In relation to the age, bone fracture was mostly occurred in dogs of less than one-year-old. This finding was similar to many previous studies (Kushwaha et al., 2011; Ali, 2013; Minar et al., 2013; Uwagie-Ero et al., 2018). This higher incidence of fracture in young dogs up to 1 year of age might be due to being playful, active nature of the young ones compared to the adult dogs, and being inexperienced to escape from the hazards. Previous study mentioned that puppies were most affected by femoral fractures due to low bone density in their development (osteogenesis) phase (Libardoni et al., 2018). This was contrary to what was reported in Kenya revealing that the incidence of appendicular fractures was higher in adults (79\%) as compared to the young dogs (21\%) (Rhangani, 2014).

Regarding cats, the bone fracture was mostly occurred in cats of one to three years old. It may be resulted from reduced knowledge of neutralization importance of tomcats and queens in Egyptian society resulting in bad habits such as escaping of cats from homes during the mating season, cat fighting, exposure to falls from heights and traffic accidents (Farghali et al., 2020). The findings of the present study revealed that the extrinsic factors which include motor vehicle accidents, falling from height, and dog bites were the major etiological agents of bone fractures in dogs. These findings were consistent with those in other studies elsewhere (Simpson, 2004; Kumar et al., 2007; Ben Ali, 2013; Elzomor et al., 2014; Rhangani, 2014; Vidane et al., 2014). A high incidence of car accidents was due to the high number of animals with access to public roads, and the owners who suppress the containment and protection measures in their homes and during outings (Libardoni et al., 2016). Meanwhile, in cats, traffic accidents followed by falling from heights and cat bites were also the most common causes (Denny and Butterworth, 2000; Senna et al., 2004; Piermattei et al., 2006; Lovrić et al., 2020).

In the current work, there was a high incidence of the appendicular long bones concerning the different bone fractures. The same was reported in previous studies (Harasen, 2003a; Thengchaisri et al., 2006; Ali, 2013; Bennour et al., 2014; Rhangani, 2014; Libardoni et al., 2016).

On the other hand, the distribution of common orthopedic conditions in canine and feline species concerning the admitted cases revealed that the prevalence of appendicular fractures was significantly higher in dogs (87\%) than in cats (71.8\%). Nearly the same result was mentioned by Bennour et al. (2014) and Singh et al. (2015). Such variation may be attributed to the owners' close observation and care directed to cats comparing with dogs, as cats are kept most of the time inside the houses (Singh et al., 2015). In the current study, fractures in the hindlimbs were higher than in forelimbs in both dogs and cats which the finding was similar to the studies reported elsewhere with a different relationship (Souza et al 2011; Ben Ali, 2013; Minar et al., 2013; Bennour et al., 2014; Rhangani, 2014; Roush, 2014; Eyarefe and Oyetayo, 2016; Uwagie-Ero et al., 2018). Most of the long bone fractures in dogs and cats occurring in hindlimbs were found in the femur, followed by tibia and fibula. These results were similar to other studies in Thailand (Thengchaisri et al., 2006), India (Shiju et al., 2010), Korea (Minar et al., 2013), Kenya (Rhangani, 2014), Egypt (50.6\%) (Elzomor et al., 2014), Philippines (Libardoni et al., 2016) and Austria (Lovrić et al., 2020). However, in the dogs' forelimb, radius and 
ulna were the bones with the most fractures (Minar et al., 2013; Bennour et al., 2014; Libardoni et al., 2016). This may be due to the low local muscle coverage (Milovancev and Ralphs, 2004).

The fracture of the humerus in cats were the most common sites of forelimb fracture. Similar results have been reported (Chandler and Beale, 2002; Senn et al., 2004; Ben Ali, 2013). Concerning both forelimbs and hindlimbs, the femur was the most affected bone, followed by tibia or fibula, radius or ulna, and humerus in dogs. Other studies showed higher incidences of occurrence with radius, ulna, and femur (Harasen, 2003b; Beale, 2004; Elzomor et al., 2014).

In cats, the femur was also the most frequently fractured bone, but there were variations in the prevalence of fractures among tibia or fibula, humerus and radius or ulna. This was in agreement with previous results (Piermattei et al., 2006; Lovrić et al., 2020). Some authors considered the fractures of the radius/ulna to be infrequent accounting for humeral fractures (Chandler and Beale, 2002). In the present study, closed fractures were more frequent than open fractures. The percentage of the open fractures were more common in cats $(23.4 \%)$ than in dogs (11\%). Open fractures were observed more frequently in the bones below the elbow and stifle in dogs due to poor soft-tissue coverage (Voss and Montavon, 2009). While, in cats, open fractures were more frequently recorded in supracondylar femoral fracture.

Incomplete fractures were recorded more frequently in dogs than in cats representing $17.7 \%$ and $3.5 \%$ out of the total fore and hind limbs long bone fractures. Greenstick, fissures, and folding fractures were the most common form of incomplete fractures among dogs. The results which were in agreement with previous findings described that greenstick or incomplete fractures were more commonly seen in juveniles (Jain et al., 2016). Complete fractures were recorded more frequently in cats than in dogs representing $96.5 \%$ and $82.3 \%$ out of total fore and hind limbs long bone fractures.

Regarding the number and direction of the fracture line, the most common type of fracture encountered in both fore and hind limbs in dogs was complete single transverse fracture $(31.7 \%)$ followed by oblique $(23.6 \%)$, comminuted $(18.6 \%)$, incomplete $(17.7 \%)$ and spiral $(8.4 \%)$ fractures. This was similar to what has been reported in previous studies (Shiju et al., 2010; Shiju et al., 2011; Ben Ali, 2013).

In cats, the most common type of fracture encountered in both fore and hind limbs was also complete single transverse $(47.7 \%)$ followed by oblique (27.9\%), spiral (12.8\%), comminuted (8.1\%) and incomplete (3.5\%) fractures. Out of 237 cases of appendicular long bone fractures in dogs, the diaphyseal fracture was the most common site of fracture (156 cases, $65.8 \%$ ), followed by distal fractures ( 54 cases, $22.8 \%$ ) and proximal fractures ( 27 cases, $11.4 \%)$. Out of 86 fracture cases in cats, $43 \%$ ( 37 cases) in the diaphyseal, $41.9 \%$ (36 cases) was in the distal part and 15.1\% (13 cases) in proximal one.

\section{CONCLUSION}

From the obtained data, it could be concluded that there was a high incidence of the appendicular long bones concerning the different bone fractures with significantly higher records in dogs than in cats. The highest records of fracture were in mongrel dogs, and cats as rescued animals. With excluding of mongrel dogs and cats, the highest incidence of canine fracture cases was recorded in Miniature breeds, and feline fracture in svelte breeds. Male dogs and cats showed a higher incidence than females. The bone fracture has mostly occurred in dogs of less than one-year-old, and in cats of one to three years old. The fracture in the hindlimbs was higher than forelimbs with the highest incidence among femur in both dogs and cats. The percentage of open fractures were more common in cats than in dogs. Incomplete fractures were recorded more frequently in dogs than in cats. In dogs, the most common fracture in the femur, tibia/fibula, humerus and radius/ulna were complete comminuted diaphyseal femoral, complete oblique diaphyseal tibial/fibular, complete transverse distal humoral, and complete transverse diaphyseal radial/ulnar fractures respectively, and in cats, were complete transverse distal femoral, complete oblique diaphyseal tibial/fibular, complete spiral diaphyseal humoral, and complete transverse distal radial/ulnar fractures respectively.

\section{DECLARATIONS}

\section{Acknowledgments}

This study was supported by the department of surgery, anesthesiology and radiology, Faculty of veterinary medicine, Cairo University, Egypt. The authors would also like to thank the team of Alpha vet pet clinic, Office Building at Al-rehab Cairo, Cairo Governorate, Egypt for their assistance in data collection.

\section{Competing interests}

The authors declare that there is no conflict of interest.

\section{Author's contribution}

Ahmed Elsayed Ahmed and Haithem Ali Mohamed Ahmed Farghali designed the study and wrote the manuscript. Abeer Ali Mahmoud Abo-Soliman and Haithem Ali Mohamed Ahmed Farghali participated in data collection and analysis, writing. All authors have read and approved the final manuscript. 
Ali LB (2013). Incidence, occurrence, classification and outcome of small animal fractures: A retrospective study (2005-2010). WASET, Journal of Animal Veterinary Sciences, 7: 191-196. DOI: https://doi.org/10.5281/zenodo.1082359

American Kennel Club (2006). The Complete Dog Book. 20th ed. New York: Ballantine Books, . Available at: https://www.amazon.com/CompleteDog-Book-20th/dp/0345476263

Appari AM, Johnson E, and Anthony DL (2013). Meaningful use of electronic health record systems and process quality of care: evidence from a panel data analysis of U.S. acute-care hospitals. Health Services Research, 48(2): 354-375. DOI: https://doi.org/10.1111/j.14756773.2012.01448.X

Beale B (2004). Orthopedic clinical techniques femur fracture repair. Clinical Techniques in Small Animal Practice, 19(3): 134-150. DOI: https://doi.org/10.1053/j.ctsap.2004.09.006

Ben Ali LM (2013). Incidence, occurrence, classification and outcome of small animal fractures: A retrospective study (2005-2010) World Academy of Science, Engineering and Technology, 7(3): 516-521. DOI: https://doi.org/10.5281/zenodo.1082359

Bennour E, Abushhiwa M, Ben Ali L, Sawesi O, Marzok M, Abuargob O, Tmumen S, Abdelhadi J, Abushima M, and Benothman M (2014). A Retrospective study on appendicular fractures in dogs and cats in Tripoli-Libya. Journal of Veterinary Advanced, 4: 425-431. Available at: https://www.ejmanager.com/mnstemps/74/74-1391243660.pdf

Borges C, Rahal S, Agostinho F, Mamprim M, Santos R, Silva FE, Carolina MA, and Monteiro FO (2016). Long bone fracture in cat. A retrospective study. Veterinaria Zootecnia, 23: 504-509. Available at: https://www.researchgate.net/publication/307598723

Brianza SZ, Delise M, Maddalena Ferraris M, D'Amelio P, and Botti P (2006). Cross-sectional geometrical properties of distal radius and ulna in large, medium and toy breed dogs. Journal of Biomechanics, 39(2): 302-311. DOI: https://doi.org/10.1016/j.jbiomech.2004.11.018

Chandler JC, and Beale BS (2002). Feline orthopedics. Clinical Techniques in Small Animal Practice, 17: 190-203. DOI: https://doi.org/10.1053/svms.2002.36607

Chaves RO (2014). Neurological diseases in dogs examined at the Veterinary Teaching Hospital of the Federal University of Santa Maria, RS: 1.184 cases (2006-2013). Pesquisa Veterinária Brasileira,34(10): 996-1001. DOI: https://doi.org/10.1590/S0100-736X2014001000012

De Arburn Parent R, Benamou J, Gatineau M, Clerfond P, and Planté J (2017). Open reduction and cranial bone plate fixation of fractures involving the distal aspect of the radius and ulna in miniature- and toy-breed dogs: 102 cases (2008-2015). Journal of the American Veterinary Medical Association , 250(12): 1419-1426. DOI: https://doi.org/10.2460/javma.250.12.1419

Denny HR, and Butterworth SJ (2000). Classification of fractures, p.83-86. In: Ibid. (Eds). A guide to canine and feline orthopedic surgery. WileyBlackwell, Oxford, P. 644. Available at: https://onlinelibrary.wiley.com/doi/pdf/10.1002/9780470699027

Dvorak M, Necas A, and Zatloukal J (2000). Complications of long bone fracture healing in dogs: Functional and radiological criteria for their assessment. Acta Veterinaria Brno, 69: 107-114. DOI: https://doi.org/10.2754/avb200069020107

Elzomor ST, Sheta EME, Farghali HA, and Ashour AE (2014). Prevalence of femoral fractures in dogs and cats .The Journal of the Egyptian Medical $\begin{array}{lcc}\text { Association, } & \text { 74: } & \text { 269-278. } \\ \text { https://www.academia.edu/download/35180585/PREVALENCE_OF_FEMORAL_FRACTURES_IN_DOGS_AND_CATS.pdf }\end{array}$

Eyarefe O, and Oyetayo SN (2016). Prevalence and pattern of small animal orthopaedic conditions at the Veterinary Teaching Hospital, University of Ibadan. Sokoto Journal of Veterinary Sciences, 14: 8. DOI: https://doi.org/10.4314/sokjvs.v14i2.2

Farghali HA, Senna NA, Khattab MS, and Shalaby RKI (2020). Prevalence of most common feline genital surgical affections in teaching veterinary hospital, Cairo university, Egypt and different pet clinics. Advances in Animal and Veterinary Sciences, 8(7): 709-719. DOI: https://doi.org/10.17582/journal.aavs/2020/8.7.709.719

Fogle B (2009). The Encyclopedia of the dog. New York: DK Publishing. Available at: https://www.amazon.com/Encyclopedia-Dog-BruceFogle/dp/0756660041

Fossum TW (2013). Small Animal Surgery. 4th.ed. St. Louis Missouri: Mosby Elsevier, p. 1619. Available at: https://www.elsevier.com/books/smallanimal-surgery/fossum/978-0-323-10079-3

Gadallah SM, Farghali H, and Magdy A (2009). Combined different fixation systems for reconstruction of comminuted diaphyseal femoral fractures in dogs. Journal of the Egyptian Veterinary Medical Association, 69(2): 29-44. Available at: https://www.academia.edu/5474710/

Harari J (2002). Treatment of feline long bone fractures. Veterinary Clinics North America Small Animal Practice, 32(4): 927-947. DOI: https://doi.org/10.1016/S0195-5616(02)00025-6

Harasen G (2003a). Common long bone fractures in small animal practice. Part 1: Canadian Veterinary Journal, 44: 333-334. Available at: https://www.ncbi.nlm.nih.gov/pmc/articles/PMC372259/

Harasen G (2003b). Common long bone fractures in small animal practice. Part 2. Canadian Veterinary Journal, 44: 503-504. Available at: https://www.ncbi.nlm.nih.gov/pmc/articles/PMC340183/

Harasen G (2004). Atraumatic proximal femoral physeal fractures in cats. Canadian Veterinary Journal, 45: 359-360. Available at: https://europepmc.org/article/med/15144117

Harasen G (2009). Feline orthopedics. Canadian Veterinary Journal, 50(6): 669-670. Available at: https://www.ncbi.nlm.nih.gov/pmc/articles/PMC2684059/

Hart B ,and Hart L (2016). Breed and gender differences in dog behavior. 10.1017/9781139161800.007. In book: The Domestic Dog. Edition: 2nd, Chapter: 7, Publisher: Cambridge University Press, Editors: James Serpell, Pp. 118-132. DOI: https://doi.org/10.1017/9781139161800.007

Helgren JA (2013). Barron's encyclopedia of cat breeds: a complete guide to the domestic cats of North America / J. Anne Helgren; with photographs by Bob Schwartz; illustrations by Michele Earle-Bridges, 2nd edition. Copyright, text and Illustrations @ 2013, 1997 by Barron's Educational Series, Inc., P. 60. Available at: https://trove.nla.gov.au/work/23422748

Hobbs SL (2012). Biological and radiological assessment of fracture healing. In Practice, 25: 26-35. DOI: https://doi.org/10.1136/inpract.25.1.26

Jain R, Parihar AS, Kamble S, Parihar YS, and Ganguly S (2016). Multiple Fractures in Tibia Bone of Dog: A Case Study. International Journal of Contemporary Microbiology, January-June, 2(1): 82-83. DOI: https://doi.org/10.5958/2395-1796.2016.00019.3

Kumar K, Mogha HP, Kinjavdekarp, Amarpal, Singh GR, Pawde AM, Kushwaha, and Kushwaha RB (2007). Occurrence and pattern of long bone fractures in growing dogs with normal and osteopenic bones. Journal of the American Veterinary Medical Association, 54: 484-490. DOI: https://doi.org/10.1111/j.1439-0442.2007.00969.x

Kushwaha RB, Gupta AK, Bhadwal MS, Kumar S, and Tripathi AK (2011). Incidence of fractures and their management in animals: a clinical study of 77 cases. Indian Journal of Veterinary Surgery, 32(1): 54-56. Available at: https://www.researchgate.net/publication/333311447 Incidence of fracture and its management in animals

Lanz OI (2002). Lumbosacral and pelvic injuries. The Veterinary clinics of North America. Small animal practice, 32(4): 949-962. DOI: https://doi.org/10.1016/S0195-5616(02)00029-3 
Libardoni RDN, Serafini GMC, Oliveira CD, Schimites PI, Chaves RO, Feranti JPS, Costa CAS, Amaral ASD, Raiser AG, and Soares AV (2016). Appendicular fractures of traumatic etiology in dogs: 955 cases 2004-2013. Ciência Rural, 46: 542-546. DOI: https://doi.org/10.1590/0103$\underline{8478 \mathrm{cr} 20150219}$

Libardoni RDN, Da Costa D, Menezes FB, Cavalli LG, Pedr otti LF and Kohlrausch PR (2018). Classification, fixation techniques, complications and outcomes of femur fractures in dogs and cats: 61 cases (2015-2016). Ciência Rural, 48(6): 1-6. DOI: https://doi.org/10.1590/0103$\underline{8478 \mathrm{cr} 20170028}$

Lovrić L, Kreszinger M and Pećin M (2020). Surgical Treatment of Canine Femoral Fractures - a Review. World Veterinary Journal, 10 (2): $137-145$. DOI: https://dx.doi.org/10.36380/scil.2020.wvj18

Johnson AL (2013). Management of specific fractures. In: Fossum, T.W. Small animal surgery. 4th.ed. St. Louis, Missouri: Mosby Elsevier, pp. 11061214. Available at: https://www.elsevier.com/books/small-animal-surgery/fossum/978-0-323-10079-3

Milovancev M, and Ralphs SC (2004). Radius/Ulna fracture repair. Clinical Techniques in Small Animal Practice, 19(3): 128-133. DOI: https://doi.org/10.1053/j.ctsap.2004.09.005

Minar M, Hwang Y, Park M, Kim S, Oh C, Choi S, and Kim G (2013). Retrospective study on fractures in dogs. Journal of Biomedical Research, 14: 140-144. DOI: https://doi.org/10.12729/jbr.2013.14.3.140

Nouh SR, Abo-Ahmad HM, Farghali HA, and Saleh MM (2014). A Retrospective Study on Canine Hip Dysplasia in Different Breeds in Egypt. Global Veterinaria, 13(4): 503-510. Available at: http://scholar.cu.edu.eg/?q=haithem_farghail/files/10.pdf

Piermattei DL, Flo G, and DeCamp C (2006). Brinker, Piermattei, and Flo's handbook of small animal orthopedics and fracture repair. 4th Edition., St. Louis, Missouri, Saunders, Elsevier, Pp. 549-553. Available at: https://www.elsevier.com/books/brinker-piermattei-and-flos-handbook-of-smallanimal-orthopedics-and-fracture-repair/decamp/978-1-4377-2364-9?aaref=https\%3A\%2F\%2Fwww.google.com\%2F

Rakha GMH, Abdl-Haleem MM, Farghali HAM, and Abdel-Saeed H (2015). Prevalence of common canine digestive problems compared with other health problems at teaching. veterinary hospital, Faculty of Veterinary Medicine, Cairo University, Egypt. Veterinary World, 8(3): 403-411. DOI: https://doi.org/10.14202/vetworld.2015.403-411

Rhangani AT (2014). Incidence, classification and management of appendicular bone fractures in dogs in Nairobi country, Kenya. A retrospective study. Master thesis of veterinary surgery, university of Nairobi, Kenya. Available at: http://erepository.uonbi.ac.ke/bitstream/handle/11295/74296/Rhangani_Incidence,\%20Classification\%20And\%20Management\%20Of\%20Appen dicular\%20Bone \%20Fractures\%20In \%20Dogs\%20In\%20Nairobi\%20County, \%20Kenya. \%20A\%20Retrospective $\% 20$ Study.pdf?sequence=5\&is Allowed=y

Roush (2014). Pet Health by the Numbers: Prevalence of Bone Fractures in dogs \& cats at 890 Banfield Pet Hospital USA. Journal of Today's Veterinary Practice, pp.1-17. Available at: https://todaysveterinarypractice.com/pet-health-by-the-numbers-prevalence-of-bone-fractures-in-dogscats/

Rrisselada M, Kramer M, and van Bree H (2005). Ultrasonographic and radiographic follow up of uncomplicated secondary fracture healing of long bones in dogs and cats. Veterinary Surgery, 34: 99-107. DOI: https://doi.org/10.1111/j.1532-950X.2005.00017.X

Scandurra A, Alterisio A, Di Cosmo A, and D'Aniello B (2018). Behavioral and Perceptual Differences between Sexes in Dogs: An Overview. Animals, 8(151): 1-26. DOI: https://doi.org/10.3390/ani8090151

Senna NA, Gadallah SM, and Zabady MK (2004). Studies on some bone disorders in cats: incidence, radiological assessment and surgical management. Journal of the Egyptian Veterinary Medical Association, 64(3): 113-137. Available at: https://scholar.google.com/scholar?cluster=10334186832027713353\&hl=ar\&as_sdt=2005\&sciodt=0,5

Shales C (2008a). Fracture management in small animal practice: 1. Triage and stabilisation. In practice, 30(6): 314-320. DOI: https://doi.org/10.1136/inpract.30.6.314

Shales C (2008b). Fracture management in small animal practice: 2. Assessment and planning. In practice, 30(7): 374-384. DOI: https://doi.org/10.1136/inpract.30.7.374

Shearer (2011). Epidemiology of orthopedic disease. Veterinary Focus, 21(2): 24-25. DOI: https://doi.org/10.1055/s-0034-1381849

Shiju MS, Ganesh R, Ayyappan S, Rao GD, Kumar RS, Kundave VR and Das BC (2010). Incidence of pelvic limb fractures in dogs: a survey of 478 $\begin{array}{lllll}\text { cases. } & \text { Veterinary } & \text { Journal, } & 3(3): & 120-121 .\end{array}$ http://www.veterinaryworld.org/Vol.3/March/Incidences\%20of\%20pelvic\%20limb\%20fractures\%20in\%20dogs.pdf

Shiju MS, Ganesh R, Ayyappan S, and Kumar RS (2011). Incidence of pectoral limb fractures in dogs: a survey of 331 cases. Tamilnadu Journal of Veterinary and Animal Sciences, 7 (2): 94-96. Available at: https://pdfs.semanticscholar.org/3cde/06a59f5912f6c7751b9276ce487ec55c0259.pdf

Simpson AM (2004). Fractures of the humerus. Clinical Techniques in Small Animal Practice, 19(3): 120-127. DOI: https://doi.org/10.1053/i.ctsap.2004.09.004

Singh R, Chandrapuria VP, Shahi A, Bhargava MK, Swamy M, and Shukla PC (2015). Fracture occurrence pattern in animals. Journal of Animal Research, 5(3): 611-616. DOI: https://doi.org/10.5958/2277-940X.2015.00103.5

Thengchaisri N, Chaiyakorn T, Pailin P, and Jadee T (2006). Classification of long bone fractures in dogs and cats, Proceeding of the 32th Veterinary Medicine and Livestock Development Annual Conference, Faculty of Veterinary Medicine Mahanakorn University of Technology, Bangkok, pp. 57-63. Available at:: http://www.vet.cmu.ac.th/cmvj/document/vol.17/number2/2019\%2017-2\%20\%5B21\%5D.pdf

Uwagie-Ero EA, Abiaezute CN, Okorie-Kanu OJ, Odigie EA, and Asemota OD (2018). Retrospective evaluation of canine fractures in southern Nigeria. Comparative Clinical Pathology, pp.1127-1132. DOI: https://doi.org/10.1007/s00580-018-2708-3

Vidane AS, Elias MZJ, Cardoso JMM, Come JAS., Harun M, and Ambrósio CE (2014). Incidence of fractures in the dogs and cats in Maputo (Mozambique) between 1998 and 2008. Brazilian Journal of Animal Science, 15: 490-494. DOI: https://doi.org/10.1590/1089-6891v15i424279

Voss K, and Montavon PM (2009). Fractures, p.129-151. In: Montavon P.M., Voss K. \& Langley-Hobbs S.J. (Ed.), Feline orthopedic surgery and musculoskeletal disease. Mosby Elsevier, Edinburgh, P. 582. DOI: https://doi.org/10.1016/B978-0-7020-2986-8.00022-7

Yu B, Han K, Zhan C, Zhang C, Ma H, and Su J (2010). Fibular head osteotomy: a new approach for the treatment of lateral or posterolateral tibial plateau fractures. Knee, 17(5): 313-318. DOI: https://doi.org/10.1016/j.knee.2010.01.002 